\title{
Correlation between Middle Finger Length and Stature of Bataknese Students in Sumatera Utara University
}

\author{
Iswary Halwadini ${ }^{1}$, Hendra Sutysna ${ }^{2}$ \\ ${ }^{1}$ Faculty of Medicine, Universitas Muhammadiyah Sumatera Utara, Jalan Gedung Arca, Kota Medan, Sumatera Utara \\ 2 Department of Anatomy and Histology, Faculty of Medicine, Universitas Muhammadiyah Sumatera Utara, Jalan Gedung \\ Arca, Kota Medan, Sumatera Utara
}

DATA OF ARTICLE:

Received: 01 Mar 2019

Reviewed: 07 Jul 2019

Revised: 11 Nov 2019

Accepted: 30 Jan 2020

*CORRESPONDENCE:

hendrasutysna@umsu.ac.id

DOI:

10.18196/mm.200243

TYPE OF ARTICLE:

Research

\section{INTRODUCTION}

Human's limb can be separated or unidentified caused by various incidents such as linear.
Abstract: Various incidents could cause a person's body to be unrecognized or separated. The estimation of stature is a major step in the identification process. Meanwhile, the found body parts are not always in the form of long bones. This study aimed to determine the relation of the length of middle finger to stature in Bataknese. This was a correlative analytic research with a cross-sectional approach. Using total sampling, the study population were Bataknese students, lecturers, and employees in Medical Faculty of Muhammadiyah University, North Sumatera. The inclusion criteria were aged 21-45 years and willing to sign an informed consent. The exclusion criteria were deformity, anomaly, inflammation, amputation of the hands, and stature disorders. The data were analysed using Pearson Correlation and Linear Regression. Mean right middle finger's hand length was $7.096(0.435)$ $\mathrm{cm}$. Mean left middle finger's hand length was $7.100(0.528) \mathrm{cm}$. Mean stature was $158.860(6.823) \mathrm{cm}$. Middle finger length was positively and significantly correlated to stature with coefficient correlation ranging from 0.780 to 0.939 ( $p<0.001)$. Linear regression equations were showing standard error of estimation ranging from 1.714 to 3,528 ( $<<0.001)$. There was strong and significantly correlation of middle finger length to stature in Bataknese.

Keywords: Middle Finger Length; Height; Linear Regression; Anthropometry.

Abstrak: Berbagai macam kejadian dapat mengakibatkan anggota tubuh seseorang tidak dikenali bahkan potongan tubuh yang terpisah. Estimasi tinggi badan merupakan langkah utama dalam proses identifikasi jenazah yang tidak dikenali. Potongan jasad yang ditemukan tidak selalu dalam bentuk tulang panjang, melainkan dapat juga dalam bentuk potongan pendek seperti jari tangan. Penelitian ini bertujuan untuk mengetahui hubungan panjang jari tengah tangan terhadap tinggi badan pada suku Batak. Melalui penelitian analitik korelatif secara potong lintang, dilakukan total sampling pada sivitas akademika bersuku Batak Fakulats Kedokteran Universitas Muhammadiyah Sumatera Utara yang memenuhi kriteria inklusi berusia 21.45 tahun dan menandatangani informed consent, serta tidak deformitas, anomali, inflamasi, dan amputasi pada tangan, serta kelainan tinggi badan, yang merupakan kriteria eksklusi. Rerata panjang jari tengah tangan kanan 7.096 $(0.435) \mathrm{cm}$. Rerata panjang jari tengah tangan kiri $7.1(0.528) \mathrm{cm}$. Rerata tinggi badan $158.86(6.823) \mathrm{cm}$. Panjang jari tengah tangan berkorelasi positif secara signifikan dengan tinggi badan $(r=0.780-0.939$; $p<0.001)$. Persamaan regresi linear menunjukkan standard error of the estimate (SEE) 1.714-3.528 $(p<0.001)$. Disimpulkan panjang jari tengah tangan (digiti III manus) berkorelasi dengan tinggi badan pada suku Batak. Tinggi badan dapat diperkirakan dengan dari panjang jari tengah tangan melalui persamaan regresi

Kata Kunci: Panjang Jari Tengah; Tinggi Badan; Regresi Linear; Antropometri

disasters, mass accidents, homicide, mutilation, until the fire that can cause the body to be unrecognized. ${ }^{1}$ Indonesia's geographical condition 
shows that Indonesia is at high risk of having natural disasters such as earthquakes, landslides, floods, tsunamis, and accidents on land, sea, and air. $^{2}$ Also, another case that allows the human body to be several parts separated is homicide by mutilation. In 2016, homicides accompanied by mutilation increased by $16.41 \%$ to 78 cases, which is 67 cases in the previous year. ${ }^{3}$

Various cases have occurred and the development of science has led to many studies on estimates of the height based on specific bone lengths, such as os ulna, os humerus, os radius, os sternum, os femur, os fibula, os tibia, and ossa metacarpal. ${ }^{4}$ In general, height plays a role in determining Body Mass Index (BMI), nutritional status, basal energy requirements, and tests that are required in the acceptance of Human Resources (HR) such as the Police, even for medicolegal purposes. ${ }^{5,6,7}$

Stature estimation can also be used as the main step in the process of identifying someone without an identity, especially if there is a mass disaster or homicide by mutilation and only found the pieces of the body that are not intact or mutilated in a person. ${ }^{8,9}$ Research about the fingers is important to determine a person's identity because the pieces of the body found as in the case of medicolegal or disaster events are not always in the form of long bones, it also can be found in the form of short pieces such as fingers. ${ }^{10}$

Although research about body stature estimates based on finger lengths has been done, there are differences in average stature in each of the previous studies. This is due to stature is affected by the interaction of genetic factors (genes) and environmental factors. According to Hardy-Weinberg's balance law, stature is lowered continuously from one generation to the next. Genetic factors from parents are permanent through the father's lineage with biological children and affect the ethnicity of an individual. This causes the ethnic included in the factors that affect stature. ${ }^{11}$

Indonesia has various ethnic groups, one of them is Bataknese, which is the third-largest population after Javanese and Sundanese with $3.58 \%$, with the main area located in North Sumatra Province. ${ }^{12}$ Bataknese is consisting of six sub-tribes such as Toba, Mandailing, Karo, Simalungun, Pak pak, and Angkola Sipirok. It becomes the largest tribe that occupies the North Sumatra region at $44.75 \% .13$ In North Sumatra, there has not been much research about the correlation between stature and the finger bones. Therefore, this study is different from previous studies because this research connects the stature and finger bones with ethnic groups. Also, the linear regression equation that will be found can be used to estimate stature based on the middle finger length of the hand, especially in the Bataknese in the Medical Faculty of the Universitas Muhammadiyah of Sumatera Utara.

Based on the explanation above, it triggers the researcher to find out the correlation between the middle finger length of the hand to the stature of the Bataknese in the Medical Faculty of Muhammadiyah University of North Sumatera.

\section{MATERIALS AND METHOD}

The study is an analytic observational research by using cross-sectional design. The sample was obtained using the total sampling method. The research subjects were academicians of the Faculty of Medicine, Muhammadiyah University of North Sumatra, including students, lecturers, and education staff who were Bataknese.

The inclusion criteria were aged 21-45 years at the time of the research. The exclusion criteria were deformity, anomaly, inflammation, amputation of the hands, having or are experiencing dislocation, fracture, trauma, or injury to the middle finger right or left hand and other bones that can affect the stature, and a history of surgical treatment on the hands, also the presence of stature building disorders such as scoliosis, kyphosis, lordosis, gigantism, cretinism, dwarfism.

All research subjects was willing to follow the research by signing an informed consent sheet. This study had received approval from the Health Research Ethics Commission of the Medical Faculty, Muhammadiyah University of North Sumatera.

This research was held at the Medical Faculty, Muhammadiyah University of North Sumatra. Data collection was done at 16.00-17.00 WIT. There is a time limitation for data collection because there are diurnal variations in stature. Stature is measured based on the vertical distance from the vertex when the head is in the Frankfurt plain position to the floor in an upright posture barefoot. ${ }^{14}$

The middle finger length of the hand is measured by the distance from the proximal phalanx (metacarpophalangeal joint) to the distal phalanx of the middle finger. The measurements were done three times and use the side of the middle finger of the anterior hand to avoid errors in measurement. The average of measurement results will recorded and processed for data analysis. The measurements are made by the same person to 
avoid mistakes between individuals. ${ }^{15}$ The data tested using Pearson Correlation and followed by Linear Regression to obtain a regression equation. ${ }^{16}$

\section{RESULT}

The study was conducted on 63 students of the Batak tribe who studied at the Medical Faculty of University of North Sumatera. The characteristics of research subjects are shown in Table 1 . The majority of respondents in this study were 21-25 years old (79.4\%), female (66.7\%).

In Table 2 and 3 seen that the length of the middle fingers of the right and left hands of male is longer than female. Table 4 showed that male is higher than female in average.

The Pearson correlation was performed and found a correlation between the middle finger length of the hand and stature. The results of the Pearson correlation is shown in Table 5.

Table 5 shows a very strong correlation on the right middle finger's hand length and stature in male and female with a correlation value between 0.8-1. Meanwhile, in Table 6 seen a strong correlation was found in the left middle finger's hand length and stature in male and female with the correlation value between $0.6-<0.8 .^{16}$

Table 1. Sample Frequency Distribution

\begin{tabular}{lcc}
\hline Distribution & Frequency & Percentage (\%) \\
\hline Gender & & \\
Male & 21 & 33.3 \\
Female & 42 & 66.7 \\
Age (years) & & \\
$21-25$ & 50 & 79.4 \\
$26-30$ & 6 & 9.5 \\
$31-35$ & 2 & 3.2 \\
$36-40$ & 2 & 3.2 \\
$41-45$ & 3 & 4.8 \\
Total & 63 & $\mathbf{1 0 0}$ \\
\hline
\end{tabular}

Table 2. The Measurement of the Right Middle Finger's Hand Length

\begin{tabular}{cc}
\hline Gender & Mean (SD) \\
\hline Male & $7.508(0.362)$ \\
Female & $6.889(0.304)$ \\
Total & $7.096(0.435)$
\end{tabular}

Table 3. The Measurement of the Left Middle Finger's Hand Length

\begin{tabular}{cc}
\hline Gender & Mean (SD) \\
\hline Male & $7.592(0.430)$ \\
Female & $6.854(0.381)$ \\
Total & $7.100(0.528)$ \\
\hline
\end{tabular}

Table 4. The measurement of the stature

\begin{tabular}{cc}
\hline Gender & Mean (SD) \\
\hline Male & $166.079(5.519)$ \\
Female & $155.070(3.804)$ \\
Total & $158.860(6.823)$ \\
\hline
\end{tabular}

Table 5. The Correlation between the Right Middle

Finger's Hand Length and Stature

\begin{tabular}{cccc}
\hline Gender & Frequency & $\begin{array}{c}\text { Pearson } \\
\text { Correlation }(\mathbf{r})\end{array}$ & $\mathbf{P}$ \\
\hline Male & 21 & 0.866 & $<0.001$ \\
Female & 42 & 0.902 & $<0.001$ \\
Total & 63 & 0.939 & $<0.001$ \\
\hline
\end{tabular}

Table 6. The Correlation between the Left Middle Finger's Hand Length and Stature

\begin{tabular}{cccc}
\hline Gender & Frequency & $\begin{array}{c}\text { Pearson } \\
\text { Correlation }(\mathbf{r})\end{array}$ & $\mathbf{P}$ \\
\hline Male & 21 & 0.784 & $<0.001$ \\
Female & 42 & 0.780 & $<0.001$ \\
Total & 63 & 0.858 & $<0.001$ \\
\hline
\end{tabular}

Table 7. The Result of Linear Regression Analysis

\begin{tabular}{|c|c|c|c|c|}
\hline \multicolumn{2}{|c|}{ Variable } & Coefficient & SEE & $\mathbf{P}$ \\
\hline \multirow{4}{*}{$\begin{array}{l}\text { Male's } \\
\text { stature }\end{array}$} & $\begin{array}{l}\text { The right } \\
\text { middle } \\
\text { finger's } \\
\text { hand }\end{array}$ & 14.481 & $\begin{array}{c}2.82 \\
8\end{array}$ & $\begin{array}{c}<0.0 \\
01\end{array}$ \\
\hline & Constant & 58.135 & & \\
\hline & $\begin{array}{l}\text { The left } \\
\text { middle } \\
\text { finger's } \\
\text { hand }\end{array}$ & 11.276 & $3 \cdot 518$ & $\begin{array}{c}<0.0 \\
01\end{array}$ \\
\hline & Constant & 79.497 & & \\
\hline \multirow{4}{*}{$\begin{array}{l}\text { Female's } \\
\text { stature }\end{array}$} & $\begin{array}{l}\text { The right } \\
\text { middle } \\
\text { finger's } \\
\text { hand }\end{array}$ & 12.590 & 1.714 & $\begin{array}{c}<0.0 \\
01\end{array}$ \\
\hline & Constant & 68.620 & & \\
\hline & $\begin{array}{l}\text { The left } \\
\text { middle } \\
\text { finger's } \\
\text { hand }\end{array}$ & 8.478 & $\begin{array}{c}2.46 \\
5\end{array}$ & $\begin{array}{c}<0.0 \\
01\end{array}$ \\
\hline & Constant & 97.261 & & \\
\hline \multirow{4}{*}{$\begin{array}{c}\text { All } \\
\text { stature }\end{array}$} & $\begin{array}{l}\text { The right } \\
\text { middle } \\
\text { finger's } \\
\text { hand }\end{array}$ & 15.985 & $\begin{array}{c}2.36 \\
6\end{array}$ & $\begin{array}{c}<0.0 \\
01\end{array}$ \\
\hline & Constant & 45.854 & & \\
\hline & $\begin{array}{l}\text { middle } \\
\text { finger's } \\
\text { hand }\end{array}$ & $13 \cdot 318$ & $\begin{array}{c}3.52 \\
8\end{array}$ & $\begin{array}{c}<0.0 \\
01\end{array}$ \\
\hline & Constant & 58.635 & & \\
\hline
\end{tabular}


Stature estimates based on the length of middle finger's hand can be obtained from linear regression analysis. Linear regression analysis will produce equations that obtain the correlation between independent variables with the dependent variable. ${ }^{16}$ Table 7 shows the results of the linear regression analysis test.

Based on the results of the linear regression analysis test in Table 7, the correlation of the length middle finger to the stature obtained through the linear regression equation is:

1. In male

a. Male's stature $(\mathrm{cm})=58.135+14.481 \times$ the length of right middle finger's hand $(\mathrm{cm})$

b. Male's stature $(\mathrm{cm})=79.497+11.276 \times$ the length of left middle finger's hand $(\mathrm{cm})$

2. In female

a. Female's stature $(\mathrm{cm})=68.620+12.590 \times$ the length of right middle finger's hand $(\mathrm{cm})$

b. Female's stature $(\mathrm{cm})=97.261+8.478 \times$ the length of left middle finger's hand $(\mathrm{cm})$

3. All sample

a. Stature $(\mathrm{cm})=45.854+15.985 \times$ the length of right middle finger's hand $(\mathrm{cm})$

b. Stature $(\mathrm{cm})=65.438+13.318 x$ the length of left middle finger's hand $(\mathrm{cm})$

\section{DISCUSSION}

Men have the average length of the right middle finger's hand which is longer than women. The average stature for men is also higher than women. This is consistent with research conducted on medical students at Syiah Kuala University, ${ }^{17}$ medical students of 2013 at Sam Ratulangi University, ${ }^{18}$ Indian populations at Manipal, ${ }^{9}$ Nigerian populations, ${ }^{19}$ and medical students at the Muhammadiyah University of North Sumatra in $2017^{7}$

The difference in average stature between men and women is caused by the different growth rates between men and women. Around the age of 10, the speed of growth between boys and girls tends to be the same. However, after 12 years old the speed of growth in boys tends to be faster than girls, this causes teenage boys is higher than girls. So theory mentioned those adult men are taller, have longer and heavier limbs with greater and denser muscle mass than adult women. ${ }^{20}$ This gender difference is also related to the age of puberty, usually, the age of puberty in men occurs longer around two years than women so it has a long time for growth.?

The average of the left middle finger's hand of the male sample in this study has a longer size compared to the middle finger of the right hand, in contrast to the results on the women sample who have an average of the middle finger of the right hand is longer than the left hand. The results of this measurement are consistent with research conducted on medical students at Syiah Kuala University and the Indian population at Manipal. ${ }^{17,9}$

The difference in the average length of the right and left middle fingers of both men and women in this study did not have a significant difference. This is consistent with research conducted on the Balinese and Bataknese in Lampung that there is no statistically significant difference in finger length of the right and left hand. ${ }^{10}$

As for anthropometric studies, it is found that the measurements obtained from the right are indeed different from the left. The difference between right and left in these individuals is called asymmetrical. ${ }^{21}$

The correlation between the length of the middle finger's hand with stature has a strong correlation (0.780-0.784) to very strong (0.8580.939). These results are consistent with studies conducted in the Indian population at Manipal, ${ }^{9}$ but different from studies at Airlangga University, where the study found a moderate correlation between the length of the middle finger's hand and stature. ${ }^{22}$ Meanwhile, the research at the University Syiah Kuala has a moderate to strong correlation for men and women. ${ }^{17}$

The length of the middle finger's hand shows an accurate correlation coefficient value indicating that the length of the middle finger's hand has a significant relationship with stature so that it can be a source of measurement for stature estimation. ${ }^{25}$ Previous research also shows that the middle finger is the most accurate measurement for estimating stature than other finger lengths. ${ }^{22}$

Stature estimates based on the length of the middle finger's hand can be obtained by finding a special regression. This research has found a linear regression equation that can be used to estimate stature from the length of the middle finger's hand. The equation has a Standard Error of the Estimate (SEE) which is ranges from 1.714 to 3.528. Standard Error of the Estimate is a good parameter to show the accuracy of the relationship between the original value and the estimated value. The accuracy of the linear regression equation is indicated by the smaller value of the SEE. ${ }^{23}$ The female sample has the lowest SEE value (1.714-2.465), this shows that the linear regression equation is more accurate in the female sample. These results are consistent 
with research on Indian populations at Manipal and Syiah Kuala University. 9,17

However, the linear regression equation found in this study is only for this study population. This is due to previous studies which stated that there were differences in hand measurements in various ethnic groups, therefore, the linear regression equation found for estimating the stature of one ethnic group in one population and can not be used to other ethnic groups. ${ }^{7}$

The difference in body proportions between one population and another is influenced by variety factors, namely 1). internal factors such as genetics that regulate the production and release of growth hormones, 2). gender factor where there are differences in growth speed between male and female starting from the age of 12 years based on research, and 3). hormones responsible for bone growth. ${ }^{10}$

The external factors are environment and ethnicity. Environment affects growth that occurs since pre-natal to post-natal. Pre-natal including maternal nutrition during pregnancy, while postnatal including health care. Several factors related to ethnicity that affect the body proportion of a population are differences in bone morphology and height among various ethnic groups. ${ }^{10}$ In Indonesia, ethnicity factors are distinctive physical characteristics. In addition, the proportion of the body is also influenced by the nutrition consumed which is needed in the process of bone growth.

Several drugs such as corticosteroids, anticonvulsants, anticoagulants consumed in high doses or long term (more than 3 months) will disrupt bone metabolism. Several diseases can affect a person's height such as gigantism, cretinism, dwarfism, scoliosis, kyphosis, lordosis, and osteoporosis. ${ }^{10}$ This causes linear regression equations for one population that may not be used in other populations and therefore different linear regression equations must be found in each population to provide the most accurate results. ${ }^{7}$

\section{CONCLUSION}

There is significant correlation between the length of the middle finger (digital III manus) and stature of the Bataknese in the Medical Faculty of Muhammadiyah University North Sumatra accompanied by a strong to the very strong correlation coefficient, thus stature can be estimated by measuring length of middle finger's hand through a linear regression equation.

\section{REFERENCES}

1. Idries AM, Tjiptomarnoto AL. Penerapan IImu Kedokteran Forensik Dalam Proses Penyidikan. Edisi Revisi. Jakarta: Sagung Seto; 2011.

2. Singh S. DVI atau Disaster Victim Identification. Majalah Kedokteran Nusantara. 2008;41(4):254258.

3. Pardani C. Tinjauan Yuridis Kriminologis Tindak Pidana Pembunuhan Disertai Mutilasi Dihubungkan Kitab Undang-Undang Hukum Pidana. Tesis. Fakultas Hukum Universitas Pasundan. 2017.

4. Sulijaya C. Hubungan antara Tinggi Badan dengan Panjang Os Tibia Percutaneous pada Pria Dewasa Suku Jawa dan Suku Lampung di Desa Negeri Sakti Kabupaten Pesawaran. Bandar Lampung. Fakultas Kedokteran Universitas Lampung. 2013.

5. Sugianto COS, dan Mexitalia M. Perbandingan Tinggi Badan dan Rentang Tangan pada Anak Balita Usia 1-5 Tahun. Medica Hospitalia. 2016;4(November 2016):88-91.

6. Luh N, Vina P, Erviantono T, Purnamaningsih E. Penerimaan Sumber Daya Manusia Brigadir Polri dalam Perspektif Governance (Studi Penerimaan Sumber Daya Manusia Kepolisian Daerah Bali Tahun Anggaran 2015). Citizen Charter, 2015: 1(1):1-10. https://ojs.unud.ac.id/index.php/citizen/article/ view/21636/14337

7. Simatupang ANH. Hubungan Panjang Telapak Tangan Terhadap Tinggi Badan pada Mahasiswa Fakultas Kedokteran Universitas Muhammadiyah Sumatera Utara. Ibnu Sina Biomedika. 2017: 1 (1)

8. Shah RK, Kanani SD, Patel BG, Tolani JN. Estimation of Stature from Head Length in Western Indian Gujarati Adolescent Population. Indian Journal of Anatomy and Physiology. 2018;5(1):42-46.

9. Rastogi P, Kanchan T, Menezes RG. Middle Finger Length - a predictor of Stature in the Indian Population. Med. Sci. Law. 2015:123-126.

10. Putri I. Korelasi Panjang Tulang Jari Telunjuk Tangan (Digiti II) Terhadap Tinggi Badan Pria Dewasa Suku Bali dan Suku Batak di Kecamatan Tanjung Senang Bandar Lampung. Medula, 2019: 8 (2): 94-99.

11. Sinaga JP. Tinggi Badan Anak Ditinjau dari Segi Faktor Genetik dan Lingkungan (Studi Antropologi Ragawi pada Suku Batak Toba). MEDIKORA. 2008: IV(2):109-129.

12. Indonesia - Sensus Penduduk 2010. Katalog Mikrodata Badan Pusat Statistik. 2014.

13. Manja CD, Amaliyah S. Panoramic Imaging 
Support to Establish The Dimension and Shape of Condylary Process of Bataknese Students and Staffs In Faculty of Dentistry University of Sumatera Utara. Dentika Dental Jurnal. 2014: 18(1): 21-26

14. Agrawal J, Raichandani L, Kataria S, Raichandani S. Estimation of Stature from Hand Length and Length of Phalanges. Journal of Evolution of Medical and Dental Science. 2013;2(50):9651-9656.

15. Kumar L, Agarwal S, Garg R, Dixit AP. Correlation between Index Finger and Stature in Uttarakhand Population. Anthropol. 2014;17(3):1007-1009.

16. Dahlan MS. Statistik untuk Kedokteran dan Kesehatan. Ed.6. Jakarta: Epidemiologi Indonesia; 2014.

17. Suryadi T, Syahrul, dan Mirza R. Penentuan Tinggi Badan Berdasarkan Panjang Jari Tengah Tangan. Jurnal Kesehatan Melayu, 2018: 1 (2)
(April 2018): 67-72.

18. Tanudjaja GN. Hubungan Tinggi Badan dengan Panjang Tangan pada Mahasiswa Fakultas Kedokteran Unsrat. Jurnal e-Biomedik. 2015;3(April):310-315

19. Index and Ring Finger Lengths and Their Correlation with Stature in a Nigerian Population. Annals of Bioanthropology. 2015;3(1):3-6.

20. Snell RS. Anatomi Klinis Berdasarkan Sistem. (Suwahjo A, Liestyawan YA, eds.). Jakarta: EGC; 2011.

21. Barut C, Sevinc O, Sumbuloglu V. Evaluation of Hand Asymetry in Relation to Hand Preference. Coll Antropol. 2011;35(4):1119-1124.

22. Fatati A. Korelasi antara Tinggi Badan dan Panjang Jari Tangan. Surabaya: Universitas Airlangga. 2013:40-44. http://journal.unair.ac.id/download-fullpapersaungf4b8efgdbfull.pdf 